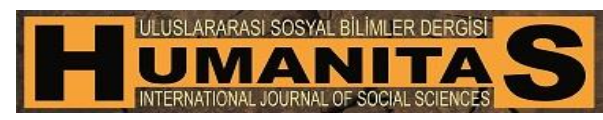

Sayı-Number: 8 Güz/Autumn 2016

ISSN: 2147-088X http://humanitas.nku.edu.tr

\title{
Yayın İlkeleri
}

Namık Kemal Üniversitesi, Fen-Edebiyat Fakültesi Humanitas - Uluslararası Sosyal Bilimler Dergisi Toplum ve İnsan Bilimleri alanlarında elde edilmiş bilimsel birikimleri ortaya koymak, güncel ve tarihsel sorunları bilimsel bir bakış açısıyla değerlendirmek ereğiyle Bahar ve Güz sayısı olmak üzere yılda iki kez yayımlanan uluslararası hakemli bir dergidir. Dergi, MLA, EBSCO, CEOOL, ASOS, ARASTIRMAX, TEİ indeksleri tarafindan dizinlenmektedir. Bunun yanında dergimiz, ULAKBIM TR Dizinde dizinlenmek üzere Aralık 2015 tarihinden beri izlenmektedir.

Humanitas'a gönderilen yazılar, daha önce başka bir dergide yayımlanmamış ya da yayımlanmak üzere gönderilmemiş, araştırmaya dayalı, etik kurallara uygun olarak yazılmış özgün makaleler olmalıdır. Bilimsel toplantılarda sunulan bildiriler, daha önce başka bir dergide veya bildiri kitapçığında yayımlanmamısssa etkinlik bilgilerinin dipnotta belirtilmesi koşuluyla yayımlanmak üzere değerlendirmeye alınabilir. Bildiri kitapçığında ya da başka bir yerde yayımlanan yazılar ne sebeple olursa olsun yayımlanmaz. Dergi yönetimi gönderilen yazıların daha önce başka bir yerde yayımlanıp yayımlanmadığını araştırmak zorunda değildir. Durumun etik sorumluluğu yazara aittir. Dergiye yayımlanmak üzere gönderilecek makalelerin biçimsel nitelikleri Fakülte Yönetim Kurulu tarafından onaylanan yazım kurallarına göre düzenlenmelidir. Yayımlanmak üzere gönderilen yazıların biçim ve içerik yönünden ön incelemesi yayın kurulu tarafından yapılır. Uygun görülen çalışmalar, bilimsel yönden değerlendirilmek üzere, yayın kurulu tarafından belirlenen çift-kör, bağımsız ve önyargısız hakemlik ilkelerine göre en az iki hakem tarafından değerlendirilir. Hakemlerin adları gizli tutulur ve tüm raporlar beş yıl süreyle saklanır. Son karar dergi yayın kurulunundur. Yayın kurulu hakemler tarafından yayın koşullarına uygun bulunmayan yazıları yayımlamamak, düzeltmek üzere yazarına geri göndermek, biçimce düzenlemek ve düzeltmek ya da kısaltmak yetkisindedir. Gönderilecek yazıların son okumasının titiz bir biçimde yapılması, vurgulama, alıntı ve kaynakların doğru biçimde kullanılması yayım aşamasında olumsuzluklarla karşılaşmamak için çok önemlidir. Dergi basıldıktan sonra ilgili sayıda yazısı bulunan yazarlara kısa süre içinde birer adet dergi iletilir. Dergimizde yayımlanan yazıların her türlü bilimsel, yazım ve hukuksal sorumluluğu yazarlarına aittir. Yayımlanmış 
yazıların tüm yayım hakları saklı olup, dergimizin adı belirtilmeden hiçbir alıntı yapilamaz.

Yayın dili: Derginin yazım dili Türkçedir. Bununla birlikte Almanca, Fransızca ve İngilizce yazılar da yayımlanabilir.

Yazım kuralları: Dergimize gönderilecek yazıların aşağıdaki biçimsel özellikleri taşıması yayım birliği açısından zorunludur.

Başlık: İçerikle uyumlu, 10-12 sözcüğü geçmeyecek biçimde büyük koyu harflerle, 11 punto yazılmalı ve sayfa ortasinda yer almalıdır.

Yazar adı ve adresi: Yazar(lar)ın adı (küçük) ve soyadı (büyük), başlığın altında ortalanmış olarak 11 puntoyla yazılmalı; unvanı, çalışığı kurum, haberleşme ve e-posta adresleri ise normal karakterde harflerle dipnot olarak belirtilmelidir.

Öz ve anahtar sözcükler: Makaleler, 200-220 sözcük arasında öz içermelidir. $\mathrm{Bu}$ özler, makalenin birinci sayfasında, başlıktan hemen sonra peş peşe verilmelidir. İngilizce ve Türkçe makalelerin özleri, makalenin dilinde olan öz ilk sırada olacak biçimde birinci sayfada verilmelidir. Fransızca ve Almanca yazılan makaleler için üç dilde öz yazılmalıdır. Bu durumda, makalenin dilinde olan öz ilk sırada, Türkçe öz onun hemen arkasında olacak biçimde birinci sayfada; İngilizce özeti ise, makalenin kaynakçasından hemen sonra yer almalıdır. Öz 10 punto, tek satır, sağdan ve soldan $\mathbf{1 ~} \mathbf{~ c m}$ içeride yer almalıdır. Öz bölümü, yazar adının hemen altından 12 nk boşluk bırakılarak başlamalıdır. Özlerin altında 3-10 sözcük arasında büyük harfle başlayan anahtar sözcükler bulunmalıdır. Öz başlığı 10 punto koyu yazılmalı ve sayfa ortasında yer almalıdır.

Ana metin: Yazı Microsoft Word yazılım programı ile boyutları 17,5 / $25 \mathrm{~cm}$ olan sayfa üzerinde Times New Roman 11 punto ile $1 \mathbf{~ c m}$ satır aralıklıve üstten $2,5 \mathrm{~cm}$, alttan $2,5 \mathrm{~cm}$, soldan $2,5 \mathrm{~cm}$, sağdan $2,5 \mathrm{~cm}$ kenar boşlukları ve 20 sayfayı geçmeyecek biçimde tek sütun halinde hazırlanarak teslim edilmelidir. Paragraflar $\mathbf{0} \mathbf{~ c m}$ girinti ile başlamalıdır. Anametin, öz bölümünün hemen altından $\mathbf{6} \mathbf{~ k}$ boşluk bırakılarak başlamalıdır.

Bölüm başıkları: Yazıda yer alan konu başlıkları Giriş’ten itibaren numaralandırılarak koyu ve sol marjdan başlamak üzere yazılmalıdır.

Şekil ve Tablolar: Şekil adı, şeklin altında, tablo başlığ tablonun üzerinde yer almalıdır. Şekil ve tablo numaraları 1, 2, 3, ... gibi verilmelidir.

Alıntı ve Göndermeler: Kaynaklara göndermeler metin içi kaynak gösterme ya da numarasız yazar-tarih sistemi APA biçemi olarak adlandırılan yöntem göz önüne alınarak yapılmalıdır. APA internet sitelerinden derlenen temel bilgiler aşağıdaki gibidir. Ayrıntılı bilgi almak için: http://www.apastyle.org/learn/tutorials/basics-tutorial.aspx sitesine başvurulabilir. Bu sistemde, metin içinde sözü edilen kaynaklara başvuruda bulunulurken yazarların soyadları ve yayın tarihi yine metin içerisinde, ilgili yerde belirtilir. Dolayısıyla, kaynak gösterimi için dipnot kullanılmasına ya da 
a.g.e. gibi ifadelere gerek yoktur. Özetleme biçiminde yapılan alıntı ve aktarmalarda sayfa numarası belirtilmez; sayfa numarası ya da numaraları, yalnızca doğrudan alıntılarda tam olarak verilir. 3 satırı geçen alıntılara, ana metne göre sadece soldan $\mathbf{1} \mathbf{~ c m}$ girinti verilmelidir. Dipnotlar, ancak çok gerekli olduğunda, metin içerisinde belirtilen görüşe açılama getirmek amacıyla ve az sayıda kullanılmalıdır.

\begin{tabular}{|l|l|}
\hline Ana Başlık Boyutu & $11 \mathrm{pt}$, ortalanmış, kalın \\
\hline Kağıt Boyutu & $17,5 \mathrm{x} 25 \mathrm{~cm}$ \\
\hline Ana Metin Üst Kenar Boşluk & $2,5 \mathrm{~cm}$ \\
\hline Alt Kenar Boşluk & $2,5 \mathrm{~cm}$ \\
\hline Sol Kenar Boşluk & $2,5 \mathrm{~cm}$ \\
\hline Sağ Kenar Boşluk & $2,5 \mathrm{~cm}$ \\
\hline İlk satır girinti & $0 \mathrm{~cm}$ \\
\hline Yazı Tipi & Times New Roman \\
\hline Yazı Tipi Stili & Normal \\
\hline Normal Metin Boyutu & $11 \mathrm{pt}$ \\
\hline Paragraf Aralığı & $3 \mathrm{nk}$ \\
\hline Satır Aralığı & $1 \mathrm{~cm}$ \\
\hline Dipnot Metni Boyutu & $9 \mathrm{pt}$ \\
\hline Alıntı Metni Boyutu & $10 \mathrm{pt}$ \\
\hline Alıntı Kenar Boşlukları & Soldan $1 \mathrm{~cm}$ \\
\hline Öz Yazı Tipi & Times New Roman \\
\hline Öz Yazı Tipi Stili & Normal \\
\hline Öz Kenar Boşlukları & Sağdan- Soldan $1 \mathrm{~cm}$ \\
\hline Öz Metin Boyutu & $10 \mathrm{pt}$ \\
\hline Öz Başlığı & $10 \mathrm{pt,} \mathrm{ortalanmış,} \mathrm{Kalın}$ \\
\hline
\end{tabular}

Tek yazarlı çalışmalar: Metinde parantez içine yazarın soyadı yazılır ve virgülle ayrılarak o çalışmanın yayın tarihi belirtilir. Eğer yazarın soyadı cümle içerisinde zaten kullanılmışsa, parantezde soyadı kullanmaya gerek yoktur.

Örnek:.. (Yılmaz, 1996, s. 268). ya da,Yılmaz'a (1996) göre,...

İki ve daha fazla yazarlı çalışmalar: Örnek: Bond ve Smith'e (1995) göre, ... ya da ... (Bond ve Smith, 1995).

Yazar sayısı 3 ve daha fazla çalışmalar: Örnek: McCrae ve arkadaşları (2000) ... ya da ... (McCrae ve ark., 2000).

Aynı yazarın (ya da yazarların) birden fazla çalışması: Örnek: Yıldırım (1982b)... ya da ... (Yıldırım, 1982b).

Kaynaklar: Yararlanılan kaynaklar, eğer varsa notlardan sonra ayrı bir sayfada "Kaynakça" başlı̆ğ altında verilmelidir. Metinde geçen tüm kaynaklar Kaynaklar listesi içinde yer almalıdır. Kaynaklar bölümünde kaynaklar yazar soyadına göre alfabetik sıra ile verilmelidir. 


\section{Kitap}

Tek Yazarlı: Gündoğdu, C. (2007). Hacı Bektâş-ı Velî, Öğretisi ve Takipçileri Hakkında Metodik Yeni Bir Yaklaşım. Ankara: Aktif Yayınları.

Çok Yazarlı: İşcan Ö. F. ve Naktiyok, A. (2005). Dijital Çağ Örgütleri. İstanbul: Beta Yayınları.

Editörlü Kitap İçinde Bölüm ya da Makale: Türer, O. (2005). Osmanlı Toplumunda Tasavvuf ve Sufiler. Ahmet Yaşar Ocak (Ed.). Osmanlı Anadolu'sunda Tarîkatların Genel Dağılımı (ss. 207-246). Ankara: T.T.K. Yayınları.

Tez: Ayık, H. (2000). Farabi de Dil-Mantık İlişkisi. (Yayımlanmamış Doktora Tezi). Erzurum: Atatürk Üniversitesi Sosyal Bilimler Enstitüsü.

Çeviri kitaplar: Hellman, H. (2001). Büyük Çekişmeler: Bilim Tarihinden Seçilmiş On Tartışma. (Çev. Füsun Baytok). Ankara: Tübitak. (1972).

Kurum Yayınlan: TÜBITTAK. (2002). 21. Yüzyılda Bilimsel Yayıncllı: Hedefler ve Yaklaşımlar. Ankara: TÜBİTAK.

Türk Dil Kurumu. (2005). Türkçe Sözlük (10. bs.). Ankara: Türk Dil Kurumu.

El kitapları: Özgüven, İ.E. (1992). HKE Hacettepe Kişilik Envanteri El Kitabı. (2. Revizyon) Ankara: Odak Ofset.

Yazarı Olmayan Yapit Anonim: The Chicago Manual of Style (14th edition). (1993). Chicago: The University of Chicago Press.

Sözlük: Altan, N. (2003). Bilgisayar Terimleri Ansiklopedik Sözlüğ̈̈ (3. bs.). Ankara: Sistem Yayınc1lı.

\section{Bilimsel Dergi Makalesi}

Makale: Gündoğdu, C. (2007). Âşsı Sümmânî’de Aşkın Metafiziği. Tasavvuf Ilmi ve Akademik Araştırma Dergisi, 8 (18), 113-154.

\section{Popüler Dergi Makalesi}

Yazarı Belli Olan: Kenar, N. (Nisan 2006). Kayıt Dışı İstihdam. Popüler Yönetim, 9, 44-47.

Yazarı Belli Olmayan: Yerel Bilginin Küreselleştirilmesi. (Nisan 2006). Focus, 12, 14-17.

Gazete Makalesi: Altan, Ç. (23 Mart 2002). Değişik bir ritimde...., Milliyet Gazetesi. 12.

\section{Diğer Yayınlar}

Yayımlanmış Bildiri: Gündoğdu, C. (2007). Pâdişah-Tarîkat Şeyhi Münasebetleri Açısından Azîz Mahmûd Hüdâyi ve Çağdaşı Abdülmecid-i Sivâsî [Bildiri]. H. Kamil Yılmaz (Ed.). Aziz Mahmud Hüdâŷ̂ Uluslararası Sempozyum Bildirileri, (20-22 Mayls 2005). (ss. 179-195). İstanbul: Üsküdar Belediye Başkanlığı. 
Yayımlanmamış Bildiri: Yeşilyaprak, B. ve Kısaç, İ. (2000). Marmara Bölgesi Depremleri Sonrası Stres Tepkileri: Karşılaştırmalı Bir Çalışma. 36. Ulusal Psikiyatri Kongresi, 3-7 Ekim, Antalya.

Poster: Önal, İ. (Ağustos 2002). Historical Perspectives on School Librarianship [Poster]. 68th IFLA General Conference and Council, Glasgow.

Patent: Kavur, K. H. (2006). Heart Flowerpot, U.S. Patent No. D518,755. Washington, DC: U.S. Patent and Trademark Office.

Ansiklopedi Maddesi: Ersoy, O. (1973). Kâğgt ve Kâğıtçıllk. Türk Ansiklopedisi (XXI, 112-115). Ankara: Milli Eğitim Bakanlığı.

Rapor: Devlet Planlama Teşkilatı. (2004). Devlet Yardımlarını Değerlendirme Özel İhtisas Komisyonu Raporu (Rapor No: DPT: 2681). Ankara: DPT.

Yasa ve Yönetmelikler: İlköğretim ve Eğitim Kanunu. (1961). T. C. Resmi Gazete, 10705, 12 Ocak 1961.

Görüşme: Mektup, e-ileti, telefon görüşmesi gibi kişisel görüşmeler elde edilebilir kaynaklar olmadıklarından kaynakçaya eklenmezler. Görüşmelere yalnızca metin içinde gönderme yapılır. Örnek: (Aşık Reyhani ile kişisel iletişim, 23 Haziran 2003).

\section{Elektronik Yayınlar}

Basılı Kitabın Elektronik Sürümü: Başar, H. (1999). Sinıf Yönetimi [Elektronik Sürüm]. İstanbul: Milli Eğitim Bakanlığı.

Basılı Makalenin Elektronik Sürümü: Akman Demir, G., Yeşilot, N. ve Serdaroğlu, P. (2006). "Neurological involvement in Behçets Disease: Clinical Characteristics, Diagnosis and Treatment" [Elektronik Sürüm]. Journal of Neurological Sciences (Turkish), 23(1), 3-7.

Makale: Yıldırım, A., Ekici, K. M. ve Şahım, T. (t.y.). "İşletmelerin Yönetim Sürecinde Sinerjik Yönetim Anlayışının Önemi”. Bilgi Vadisi, 1(2). Erişim tarih: 04 Nisan 2006 ,

http://www.bilgivadisi.net/idas/index.php=view\&id=86\&Itemid=59

Veritabanında Makale ya da Madde: Coşkun, T., Bozoklu, S., Özenç A. ve Özdemir, A. (1998). "Effect of Hydrogen Peroxide on Permeability of the Main Pancreatic Duct and Morphology of the Pancreas". The American Journal of Surgery, 176 (1), 5358. Erişim tarihi: 25 Nisan 2006, Science Direct.

Rapor: Devlet Planlama Teşkilatı. (Temmuz 2004). "e-Dönüşüm Türkiye Projesi Kısa Dönem Eylem Planı: Değerlendirme Raporu (Rapor No: 2)." Erişim: 02 Nisan 2006, http://212.175.33.22/kdep/rapor/ KDEPHaziran2004.pdf

Anonim Ă Sayfası: "Bilim Etiği ve Bilimde Sahtekârlık." (t.y.). Erişim: 04 Nisan 2006,http://www.aek.yildiz.edu.tr/bilim.htm

Ăg Sitesinden Erişilen A $\breve{g}$ Sayfası: Gordon, C. H., Simmons, P. ve Wynn, G. (2001). "What it is, and how to Avoid it". Erişim Tarihi: 04 Nisan 2006, University of British Columbia A $\breve{g}$ Sitesi: http://www.zoology.ubc.ca/bpg/Advising/ Plagiarism.htm 
Ă Sitesi: Tema Vakfi. (t.y.). Erişim tarihi: 04 Nisan 2006, http://www.tema.org.tr

Elektronik Kaynak Haber, Tartışma Grubu ya da Forum İletisi: Işı1k, E. (5 Kasım 2003). Bitki Kütüphanesi [İleti No: 8]. Erişim tarihi: KutupL, http://listproc.metu.edu.tr.9000/reguser/KUTUPL/kutupl.1/msg08.html

Web Sitesine Atıfta Bulunma: Bir Web sitesinin tümüne (sitedeki belli bir sayfaya değil) atıfta bulunmak için, sitenin adresini vermek yeterli olacaktır.

Yazılım Sanayicileri Derneği (http://www.yasad.org.tr)

Özet: Irak, M. (1998). "Uyku ve Bilgi İşleme Süreçleri.” [Özet] Türk Psikoloji Yazıları, 1 (1), 17-30. Erişim tarihi: 08 Ocak 2000. http://www.psikolog.org.tr/tpy/1/metehan.htm

Bir Web sitesinde belirli bir sayfa: Türk psikologlar derneği deprem özel çalışma grubu basın bildirisi: Deprem bölgesi eğitim öğretim yılına hazır mı (22 Eylül, 1999) Ankara: Türk Psikologlar Derneği. Erişim tarihi: 08 Ocak 2000.

http://www.psikolog.org.tr/deprem/basinbildiri5.htm

\section{Elektronik Dergiler}

Dergide Basılan ve İnternette Yayınlanan Elektronik Dergilerden Alınan Makaleler: Gündoğdu, C. (2005). "Mevlânâ'nın Mesnevî’sinde Mânâ Dili”, [Elektronik Versiyon]. Tasavvuf Imi ve Akademik Araştırma Dergisi.14, 221231.

Sadece İnternette Yayımlanan Elektronik Dergilerden Alınan Makaleler: Önder, M. (2008). "Medya Kıskacındaki Çocuklar”. Makale 9. Erişim tarihi: 25 Nisan 2009. http://www.dinbilimleri.com/dergi/cilt8/sayi4/makale/onder.pdf

Elektronik veri tabanları için tarih (CD-ROMlar için belirtilmez), kaynak (örn., SSCI, ERIC) ve veritabanının adı ile diğer ek bilgiler (madde numarası gibi) belirtilmelidir.

Web kaynakları için ise, o veritabanına giriş sayfasının adresi (URL) verilmelidir. (örnek., http://www.ebscho.com).

Saracho, O, N. (1999). A Factor analysis of preschool childrens play strategies and cognitive style. Educational Psychology, 19 (2), pp 165. [Erişim tarihi: 08 Ocak 2000 EBSCO (Academic Search Elite), http://www.ebsco.com]

\section{Radyo ve Televizyon Programları}

Film: Türkiye Radyo ve Televizyon Kurumu (Yapımc1), Özakman, T. (Senarist) ve Öztan, Z. (Yönetmen). (1996). Kurtuluş [Film]. Türkiye: Türkiye Radyo ve Televizyon Kurumu.

Radyo ve Televizyon Programi: Berki, T. (Yapimc1). (08 Mart 2006). Promenad [Radyo Program1]. Ankara: RadyoHacettepe.

\section{Müzik ve Sahne Sanatları}

Konser / Resital: Erkin, U. C. Piyano Sonatı. T. Berki. Ankara: Bilkent Konser Salonu. (09 Nisan 2006). 
Opera: Puccini, G. Gianni Schichi (Libretto: G. Forzano). Yönetmen: R. Simone, Başrol: C. Guelfi ve D. Dessi, Orkestra Şefi: G. Gelmetti. Roma: Teatro della Opera. (22 Ocak 2002).

Bale: Kınıklı, Ö. Giriş, Gelişme, Sonuç. Başrol: Ö. Kınıklı. Ankara: Devlet Opera ve Balesi Büyük Sahne. (15 Nisan 2006).

Tiyatro: Shakespeare, W., Hamlet. Yönetmen: J. Gielgud, Başrol: R. Burton. Boston: Shubert Theatre. (04 Mart 1964).

Müzik Yapıtı: Beethoven, L. v. (1812). Symphony, No. 7 in A, Opus 92. New York: Dover. (1998)

Erkin, U. C. (1932). Keman ve Piyano İçin Improvisation. Ankara: Devlet Konservatuvar1. (1958).

Müzik Kaydı: Erkin, U. C. (1995). Altı Prelüd [V. Erman]. Ulvi Cemal Erkin: Complete works for piano solo [CD]. Avusturya: Hungaroton Classic. (1994).

\section{Plastik Sanatlar}

Kişisel Sergi: Misman, H., Resim Sergisi. Ankara: Çankaya Belediyesi Çağdaş Sanatlar Merkezi. (03-31 Mart 2006)

Karma Sergi: Hacettepe Üniversitesi Güzel Sanatlar Fakültesi Heykel Bölümü Sergisi. Ankara: Çankaya Belediyesi Çağdaş Sanatlar Merkezi. (20-30 Nisan 2006).

Sanat Yapitı

Koleksiyon ya da Müzelerde: Sayın, Z. (2003). Esinti [Grafik]. Francavilla al Mare, Italya: Michetti Müzesi.

Yayınlarda: İzer, Z. F. (1986). Balkondan Susamlar [Resim]. S. M. Erinç. Zeki Faik İzer: 1905-1988 (s. 175). Ankara: Türkiye Halk Bankası. (1990) 



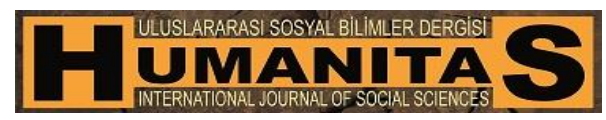

Sayı-Number: 7

ISSN: 2147-088X

Bahar/Spring 2016

http://humanitas.nku.edu.tr

\section{Principles of Publication}

Humanitas - International Journal of Social Sciences is a double blind peerreviewed international journal, published twice a year Spring and Autumn by the Faculty of Arts and Sciences at Namık Kemal University. The aim of the journal is to publish research papers in the fields of social and human sciences, to evaluate contemporary and historical problems with a scientific approach. The journal is indexed on MLA, EBSCO, CEOOL, ASOS, ARASTIRMAX, TEI. Besides, the journal has been viewed since December 2015 in ULAKBİM TR index.

The articles that are sent to Humanitas should be based on research, and original which follow ethical rules, and should not have been published or sent to be published before. The papers presented in scientific conferences are taken for evaluation to be published, if they are not published in any journal or conference book, on condition that its information is given as a footnote. These articles which are published in any journal are not published, in any case. The editorial board is not responsible for checking these articles if they have been published before, or not. This ethic responsibility belongs to the writer. The form of the articles should be organized according to spelling rules, confirmed by administration. The articles sent to be published are checked by the publication commission for their form and content before they are published. The texts that are confirmed are evaluated scientifically by at least two reviewers according to double-blind independent and unprejudiced peerreviewing principles. The names of the reviewers are not revealed and evaluation documents are kept for a five-year period. The last decision belongs to the publication commission. Publication commission has the authority not to publish the text, which is not approved by the editorial board, and send it back to its writer to be corrected, re-arranged, or its content changed or reduced. It is very important to make the last revision carefully, to use quotations and citation correctly in order not to have problems during the publication process. When the journal is published, one copy is sent to the each writer in a short time. The writers, whose texts are published in our journal, are responsible for all the scientific, orthographical and legal aspects. All copyrights of the published texts are reserved. It is illegal to make quotations without citing our journal's name.

Language: The language of publication is Turkish. Besides, articles in German, French and English are also accepted. 
Spelling rules: The texts that are sent to be published must have these qualifications below considered for publication unity.

Title: It should be related to the content, and it should be written centered, with capital and bold letters, $11 \mathrm{pt}$, containing no more than 10-12 words.

Name and address of the writer: First name (small) and surname (capital) of the writer(s) should be written $\mathbf{1 1} \mathbf{~ p t}$, centered and bold below the title. Also, the position, institution, communication and e-mail addresses should be indicated as a footnote with standard character letters.

Abstract and keywords: Articles should contain an abstract, which should be between 200-220 words. The abstracts should be presented on the first page of the article just after the title. English and Turkish abstracts should be given on the first page and the abstract which is in the same language with the main text is placed as the first. Three abstracts should be written for the articles written in French and German. In this case, the abstract with the main language should be given as the first, and Turkish abstract after the first one on the first page, and English abstract should be just after the bibliography of the article. The abstract must be10 pt, single space, and must have $\mathbf{1} \mathbf{~ c m}$ margins on the right and left sides. At the end of the abstracts, there should be keywords containing between 3-10 words. Abstract must start just below the name of the writer, with 12 nk space. The title of the abstract should be written centered, with capital and bold letters, 10 pt.

Main text: The text, containing no more than 20 pages, should be written in Microsoft Word Page (17,5 x $25 \mathrm{~cm})$, using Times New Roman,11 pt, $1 \mathrm{~cm}$ line spacing, one column and $0 \mathrm{~cm}$ indents, and $2,5 \mathrm{~cm}$ top, 2,5 cm bottom, 2,5 cm left, $2,5 \mathrm{~cm}$ right margins. Main text must start just below the abstract, with $\mathbf{6} \mathbf{~ n k}$ space.

Chapter titles: The topics in the text should be written with numbers beginning from introduction, bold and beginning with left indent.

Figures and boards: The title of the figure should be given under the figure; the title of the board should be above the board. The numbers should be given like these: 1, 2, 3, etc.

Quotations and references: References to the sources must be given by using the citing in-text or date-writer without numbers format (APA format). In this format, the writer's last names and publication date are stated on the right place in the text while referring to the sources that are mentioned in the text. Thus, there is no need to use footnotes for the citation or the terms like idem or ibidem. Quotations in the shape of summary are not given with page numbers; they are only given while quoting directly. The quotations with more than $\mathbf{3}$ lines must have $\mathbf{1} \mathbf{~ c m}$ margin on the left side only, considering the main text. Footnotes should be used to make an explanation for the statement that is given in the text, and also their length should be minimal. You can apply for http://www.apastyle.org/learn/tutorials/basics-tutorial.aspx for detailed information. 


\begin{tabular}{|l|l|}
\hline Size of Main Title & $11 \mathrm{pt}$, centered, bold \\
\hline Preferred Page Size & $17,5 \mathrm{x} 25 \mathrm{~cm}$ \\
\hline Top Margin & $2,5 \mathrm{~cm}$ \\
\hline Bottom Margin & $2,5 \mathrm{~cm}$ \\
\hline Left Margin & $2,5 \mathrm{~cm}$ \\
\hline Right Margin & $2,5 \mathrm{~cm}$ \\
\hline First line indent & $0 \mathrm{~cm}$ \\
\hline Font & Times New Roman \\
\hline Font Type Style & Normal \\
\hline Size of Normal Text & $11 \mathrm{pt}$ \\
\hline Space Between Paragraphs $3 \mathrm{nk}$ \\
\hline Space Between Lines & $1 \mathrm{~cm}$ \\
\hline Size of Foot Note & $9 \mathrm{pt}$ \\
\hline Size of Block Quotations & $10 \mathrm{pt}$ \\
\hline Block Quotations Margins & $1 \mathrm{~cm}$ left \\
\hline Abstract Font & Times New Roman \\
\hline Abstract Font Type Style & Normal \\
\hline Abstract Margins & $1 \mathrm{~cm}$ left and right \\
\hline Size of Abstract & $10 \mathrm{pt}$ \\
\hline Title of Abstract & $10 \mathrm{pt}$, centered, bold \\
\hline
\end{tabular}

Works with single writer: The last name of the writer is written in brackets in the text, and is separated with a coma, before stating the date of the work. If the last name of the writer is used in the sentence already, there is no need to write the last name in the brackets.

Example: ... (Y1lmaz, 1996, p.258) or, according to Y1lmaz (1996)...

Works with two or more writers: Example: According to Bond and Smith (1995) ....or .... (Bond and Smith, 1995).

Works with three or more writers: Example: McCrae and his colleagues (2000) ... or ... (McCrae and his colleagues, 2000)

One or more works of the same writer(s): Example: Yıldırım (1982b) ...or... (Yıldırım, 1982b)

Sources: The cited sources should be given on a different page under the Bibliography title, after the Notes, if there are any. Sources must be written according to the writer's last names and in an alphabetic order.

Books

Single writer: Gündoğdu, C. (2007). Hacı Bektâş-ı Velî, Öğretisi ve Takipçileri Hakkında Metodik Yeni Bir Yaklaşım. Ankara: Aktif Yayınları.

Multiple writers: İşcan Ö. F. ve Naktiyok, A. (2005). Dijital Çağ Örgütleri. İstanbul: Beta Yayınları. 
Chapter or article in a book with editor: Türer, O. (2005). "Osmanl1 Toplumunda Tasavvuf ve Sufiler.Ahmet Yaşar" Ocak (Ed.). Osmanlı Anadolu`sunda Tarikatların Genel Dă̆ılımı (pp.207-246). Ankara: T.T.K. Yayınları.

Thesis: Ay1k, H. (2000). Farabi de Dil-Mantık Ilişskisi. (inedit Phd ). Erzurum: Atatürk University Sosyal Bilimler Enstitüsü.

Translated books: Hellman, H. (2001). Büyük Çekişmeler: Bilim Tarihinden Seçilmiş On Tartışma. (Çev. Füsun Baytok). Ankara: Tübitak. (1972).

Institution publications: TÜBİTAK. (2002).21. Yüzyllda Bilimsel Yayıncllı: Hedefler ve Yaklaşımlar. Ankara: TÜBITAK.

Türk Dil Kurumu. (2005). Türkçe Sözlük (10. bs.). Ankara: Türk Dil Kurumu.

Handbooks: Özgüven, İ.E. (1992). HKE Hacettepe Kişilik Envanteri El Kitabı. (2. Revizyon) Ankara: Odak Ofset.

Anonymous: The Chicago Manual of Style (14th edition). (1993). Chicago: The University of Chicago Press.

Dictionaries: Altan, N. (2003). Bilgisayar Terimleri Ansiklopedik Sözlüğ̈̈ (3. bs.). Ankara: Sistem Yayınc1lık.

\section{Articles in scientific journal}

Articles in Turkish: Gündoğdu, C. (2007). Âşık Sümmân̂̂'de Aşkın Metafiziği. Tasavvuf İlmi ve Akademik Araştırma Dergisi, 8 (18), 113-154.

Articles in foreign languages: Kurbanoğlu, S. S. (2003). Self Efficacy: A Concept Closely Linked to İnformation Literacy and Lifelong Learning [Öz Yeterlik: Bilgi Okuryazarlığı ve Yaşam Boyu Öğrenmeyle Yakından İlişkili Bir Kavram]. Journal of Documentation, 59, 635-646.

\section{Articles in popular journals}

Known author(s): Kenar, N. (Nisan 2006). Kayıt Dışı İstihdam. Popüler Yönetim, 9, 44-47.

Anonymous: Yerel Bilginin Küreselleştirilmesi. (Mart2006). Focus, 12, 14-17.

Newspaper article: Altan, Ç. (23 Mart 2002). Değişik bir ritimde.... Milliyet Gazetesi. 12.

\section{Other publications}

Proceedings published: Gündoğdu, C. (2005). Pâdişah-Tarîkat Şeyhi Münasebetleri Açısından Azîz Mahmûd Hüdâyi ve Çağdaşı Abdülmecid-i Sivâsî [Bildiri]. H. Kamil Yılmaz (Ed.). Aziz Mahmud Hüdâŷ̂ Uluslararası Sempozyum Bildirileri, 20-22 Mayls 2007). (pp. 179-195). İstanbul: Üsküdar Belediye Başkanlığı.

Proceedings unpublished: Yeşilyaprak, B. ve Kısaç, İ. (2000). Marmara Bölgesi Depremleri Sonrası Stres Tepkileri: Karşılaştırmalı Bir Çalışma. 36. Ulusal Psikiyatri Kongresi, 3-7 Ekim, Antalya. 
Poster: Önal, İ. (Ağustos 2002). Historical Perspectives on School Librarianship [Poster]. $68^{\text {th }}$ IFLA General Conference and Council, Glasgow.

Patent: Kavur, K. H. (2006). Heart Flowerpot, U.S. Patent No. D518,755. Washington, DC: U.S. Patent and Trademark Office.

Encyclopedia subject: Ersoy, O. (1973). Kağıt ve Kağıtçıllk. Türk Ansiklopedisi (XXI, 112-115). Ankara: Milli Eğitim Bakanlığı.

Report: Devlet Planlama Teşkilatı. (2004). Devlet Yardımlarını Değerlendirme Özel İhtisas Komisyonu Raporu (Rapor No: DPT: 2681). Ankara: DPT.

Laws and regulations: İlköğretim ve Eğitim Kanunu. (1961). T. C. Resmi Gazete, 10705, 12 Ocak 1961.

Interview: Because they are not accessible sources, letters, e-mails, phone calls and other similar personal interactions are not added to bibliography. These are referred in the text only. Example: (Personal contact with Aşı Reyhani, 23th June 2003).

Electronic publications: Başar, H. (1999). Sinıf Yönetimi [Electronic Version]. İstanbul: Milli Eğitim Bakanlığı.

Electronic version of a published book: Akman Demir, G., Yeşilot, N. ve Serdaroğlu, P. (2006). Neurological involvement in Behçets Disease: Clinical Characteristics, Diagnosis and Treatment [Elektronic Version]. Journal of Neurological Sciences (Turkish), 23(1), 3-7.

Article: Yıldırım, A., Ekici, K. M. ve Şahım, T. (t.y.). İşletmelerin Yönetim Sürecinde Sinerjik Yönetim Anlayışının Önemi. Bilgi Vadisi, 1(2). Date of Access: 4th of April 2006,

http://www.bilgivadisi.net/idas/index.php=view\&id=86\&Itemid=59

Article or subject in database: Coşkun, T., Bozoklu, S., Özenç A. ve Özdemir, A. (1998). Effect of Hydrogen Peroxide on Permeability of the Main Pancreatic Duct and Morphology of the Pancreas. The American Journal of Surgery, 176(1), 53-58. Date of Access: 25th of April 2006, ScienceDirect.

Report: Devlet Planlama Teşkilatı. (July 2004). e-Dönüşüm Türkiye Projesi Kısa Dönem Eylem Planı: Değerlendirme Raporu (Report No: 2). Access: 2th of April 2006, http://212.175.33.22/kdep/rapor/ KDEPHaziran2004.pdf

Anonymous web page: Bilim Etiği ve Bilimde Sahtekarlık. (t.y.). Access: 4th of April 2006,http://www.aek.yildiz.edu.tr/bilim.htm

Web page connected through web site: Gordon, C. H., Simmons, P. ve Wynn, G. (2001). What it is, and how to Avoid it. Date of Access: 4th of April 2006, University of British Columbia A $\breve{g}$ Sitesi:

http://www.zoology.ubc.ca/bpg/Advising/ Plagiarism.htm

Web site: Tema Vakfi. (t.y.). Date of Access: 4th of April 2006, http://www.tema.org.tr 
Electronic sources - news, discussion group or forum message: Iş̧1k, E. (5th of November 2003). Bitki Kütüphanesi [Message No: 8]. Date of Access: Kutup L, http://listproc.metu.edu.tr.9000/reguser/KUTUPL/kutupl.1/msg08.html

Citing a web site: To cite a web site completely (not a particular page), it is enough to give the web site address.

Yazılım Sanayicileri Derneği (http://www.yasad.org.tr)

Abstract : Irak, M. (1998). Uyku ve Bilgi İşleme Süreçleri. [Abstract] Türk Psikoloji Yazılart, 1 (1), 17-30. Date of Access: 8th of January 2000. http://www.psikolog.org.tr/tpy/1/metehan.htm

Web site particular pages: Türk psikologlar derneği deprem özel çalışma "grubu basın bildirisi: Deprem bölgesi eğitim öğretim yılına hazır mı? (22 Eylül, 1999) Ankara: Türk Psikologlar Derneği. Date of Access: 8th of January 2000. http://www.psikolog.org.tr/deprem/basinbildiri5.htm

\section{Electronic journals}

Articles published in a journal and taken from electronic journals on Internet: Gündoğdu, C. (2005). Mevlânâ'nın Mesnevî’sinde Language of Meaning, [Elektronic Version]. Tasavvuf İmi ve Akademik Araştırma Dergisi. 14, 221-231.

Articles taken only from electronic journals on Internet: Önder, M. (2008). Medya Kıskacındaki Çocuklar. Makale 9. Date of Access: 25th of April 2009. http://www.dinbilimleri.com/dergi/cilt8/sayi4/makale/onder.pdf

The date (not for CD-ROMs), source (e.g. SSCI, ERIC), the name of the database and other information (such as item number) must be given for the electronic databases. For the web sources, the address of the entry page of the database (URL) must be given. (Example; http://www.ebscho.com).

Saracho, O, N.(1999). A Factor analysis of preschool childrens play strategies and cognitive style. Educational Psychology, 19 (2), pp 165. [Date of Access: 8th of January 2000 EBSCO (Academic Search Elite), http://www.ebsco.com]

\section{Radio and television programs}

Film: Türkiye Radyo ve Televizyon Kurumu (Producer), Özakman, T. (Script Writer) ve Öztan, Z. (Director). (1996). Kurtuluş [Film]. Türkiye: Türkiye Radyo ve Televizyon Kurumu.

Radio and television programs: Berki, T. (Producer). (8th of March 2006). Promenad [RadioProgram]. Ankara: RadyoHacettepe.

\section{Music and theatre arts}

Concert/Recital: Erkin, U. C. Piyano Sonatı. T. Berki. Ankara: Bilkent Konser Salonu. (9th of April 2006).

Opera: Puccini, G. Gianni Schichi (Libretto: G. Forzano). Director: R. Simone, Leading Role: C. Guelfi ve D. Dessi, Orchestra Chief: G. Gelmetti. Roma: Teatro dell Opera. (22nd of January 2002). 
Ballet: Kınıklı, Ö. Giriş, Gelişme, Sonuç. Başrol: Ö. Kınıklı. Ankara: Devlet Opera ve Balesi Büyük Sahne. (15th of April 2006).

Theatre: Shakespeare, W., Hamlet. Director: J. Gielgud, Başrol: R. Burton. Boston: Shubert Theatre. (4th of March 1964).

Musical production: Beethoven, L. v. (1812). Symphony, No. 7 in A, Opus 92. New York: Dover. (1998)

Erkin, U. C. (1932). Improvisation for Violin and Piano. Ankara: Devlet Konservatuvar1. (1958).

Music record: Erkin, U. C. (1995). Altı Prelüd [V. Erman]. Ulvi Cemal Erkin: Complete works for piano solo [CD]. Avusturya: Hungaroton Classic. (1994).

Plastic arts

Exhibition Personal: Misman, H., Art Gallery. Ankara Municipality of Çankaya, Modern Arts Center. $\left(3^{\text {rd }}-31\right.$ st of March 2006)

Exhibition Mixed: Hacettepe University Exhibition of the Department of Sculpture, Faculty of Fine Arts. Ankara: Çankaya Belediyesi Çağdaş Sanatlar Merkezi. (20 $-30^{\text {th }}$ of April 2006).

\section{Art works}

In collections or museums: Sayın, Z. (2003). Esinti [Graphic]. Francavilla al Mare, Italy: Michetti Museum.

In publications: İzer, Z. F. (1986). Balkondan Susamlar [Painting]. S. M. Erinç. Zeki Faik İzer: 1905-1988 (s. 175). Ankara: Türkiye Halk Bankası. (1990) 